\title{
The Response of Layer Hen Productivity and Egg Quality to an Additional Limestone Source When Offered Diets Differing in Calcium Concentrations and the Inclusion of Phytase
}

\author{
Isabelle Ruhnke ${ }^{1}{ }^{\oplus}$, Yeasmin Akter ${ }^{2}{ }^{\circledR}$, Terence Zimazile Sibanda ${ }^{1}$, Aaron J. Cowieson ${ }^{3}$, Stuart Wilkinson ${ }^{4}$, \\ Stephanie Maldonado ${ }^{2}$, Mini Singh ${ }^{2}{ }^{-1}$, Patrick Hughes ${ }^{2}$, Dylana Caporale ${ }^{2}$, Stephan Bucker ${ }^{2}$ \\ and Cormac John $\mathrm{O}^{\prime}$ Shea ${ }^{5,6,7, *(1)}$
}

check for updates

Citation: Ruhnke, I.; Akter, Y.;

Sibanda, T.Z.; Cowieson, A.J.;

Wilkinson, S.; Maldonado, S.; Singh, M.; Hughes, P.; Caporale, D.; Bucker, S.; et al. The Response of Layer Hen Productivity and Egg Quality to an Additional Limestone Source When Offered Diets Differing in Calcium Concentrations and the Inclusion of Phytase. Animals 2021, 11, 2991. https://doi.org/10.3390/ani11102991

Academic Editor: Sylwester Swiątkiewicz

Received: 9 August 2021

Accepted: 14 October 2021

Published: 18 October 2021

Publisher's Note: MDPI stays neutral with regard to jurisdictional claims in published maps and institutional affiliations.

Copyright: (c) 2021 by the authors. Licensee MDPI, Basel, Switzerland. This article is an open access article distributed under the terms and conditions of the Creative Commons Attribution (CC BY) license (https:/ / creativecommons.org/licenses/by/ $4.0 /)$.
1 School of Environmental and Rural Science, University of New England, Armidale, NSW 2351, Australia; iruhnke@une.edu.au (I.R.); tsiband2@une.edu.au (T.Z.S.)

2 Sydney School of Veterinary Science, University of Sydney, Sydney, NSW 2570, Australia; yeasmin.akter@sydney.edu.au (Y.A.); steph.maldonado@outlook.com (S.M.); mini.singh@sydney.edu.au (M.S.); pjhughes1995@gmail.com (P.H.); dcap0531@uni.sydney.edu.au (D.C.); stephan-buecker@gmx.net (S.B.)

3 DSM Nutritional Products, Wurmisweg, 576 Kaiseraugst, Switzerland; aaron.cowieson@dsm.com

4 Feedworks, Romsey, VIC 3434, Australia; stuart.wilkinson@feedworks.com.au

5 School of Life and Environmental Sciences, University of Sydney, Sydney, NSW 2570, Australia

6 School of Biosciences, University of Nottingham, Loughborough, Leicestershire LE12 5RD, UK

7 Department of Bioveterinary and Microbial Sciences, Technological University of the Shannon, Midlands Midwest, N37 HD68 Athlone, Ireland

* Correspondence: Cormac.OShea@tus.ie

Simple Summary: Dietary calcium is essential for optimal egg production and quality in laying hens, but high concentrations can impede the digestibility of other dietary components. The provision of limestone grit in addition to the main diet may help maintain overall calcium intake while allowing a reduction in dietary calcium levels. The impact of phytase, an enzyme that increases calcium availability in the gut, on the voluntary consumption of limestone grit is unknown. Here, the capacity for hens with access to a separate limestone grit source to modify Ca consumption when offered varying dietary Ca levels and phytase was evaluated. Dietary phytase reduced limestone grit consumption. Egg production was unaffected by reducing dietary calcium levels or the phytase addition. Eggshell measurements worsened in line with decreasing dietary calcium levels despite the provision of limestone grit. In summary, the provision of limestone grit resulted in comparable egg production but not eggshell quality in hens offered suboptimal levels of dietary calcium.

Abstract: Laying hens require substantial quantities of calcium $(\mathrm{Ca})$ to maintain egg production. However, maintaining recommended dietary $\mathrm{Ca}$ through inclusion of limestone may impede nutrient digestibility, including that of other minerals. It was hypothesized that providing a separate source of dietary $\mathrm{Ca}$ in the form of limestone grit would preserve Ca intake of hens offered diets containing suboptimal Ca concentrations. Furthermore, the impact of dietary phytase at a "superdosing" inclusion rate on the voluntary consumption of limestone grit was evaluated. One hundred and forty-four laying hens (19 weeks of age) were assigned to one of six dietary treatments in a $3 \times 2$ factorial arrangement comprising three dietary Ca concentrations $(40,30$, and $20 \mathrm{~g} / \mathrm{kg}$ ) and \pm dietary phytase (3500 FYT/kg diet) on an ad libitum basis for six weeks. Limestone grit ( $3.4 \pm 1.0 \mathrm{~mm}$ ) was provided to all hens ad libitum. Hens offered diets containing phytase consumed significantly less limestone grit $p=0.024)$. Egg weight, rate of lay, and egg mass were unaffected by dietary treatment $(p>0.05)$. Egg shell weight $\%(p<0.001)$, shell thickness $(p<0.001)$, and shell breaking strength $(p<0.01)$ decreased in line with dietary Ca levels. In summary, dietary superdosing with phytase reduced the consumption of a separate limestone source in individually housed, early lay ISA Brown hens. Egg shell quality variables but not egg production worsened in line with lower dietary Ca levels.

Keywords: behavior; choice-feeding; feed; performance; poultry; selection; matrix; minerals 


\section{Introduction}

Laying hens have a large requirement for dietary Ca to satisfy eggshell synthesis, and this is typically satisfied by dietary inclusion of limestone and other various calciumcontaining ingredients. However, dietary limestone is associated with an increase in the $\mathrm{pH}$ of avian gastrointestinal tract contents $[1,2]$ which interferes with the enzymatic hydrolysis of digesta. Luminal Ca also binds to plant-derived phytate, forming Ca-phytate complexes which are less susceptible to degradation in the gastrointestinal tract, thus reducing the availability of $\mathrm{Ca}, \mathrm{P}$, and various other nutrients $[3,4]$. Reducing dietary $\mathrm{Ca}$ has been one strategy explored by several investigators to lower the quantity of Ca-phytate complexes. However, while reduced Ca intake may not immediately impact egg mass, ultimately, egg and bone composition and mechanical breaking strength can be impaired $[5,6]$.

Providing a choice of diets differing in nutrient profile is a dietary strategy that allows birds to select nutrients based on individual requirements. Holcombe et al. [7] reported how hens preferred high Ca diets when offered a choice. This concept has been extensively reviewed by Rose and Kyriazakis [8] and more recently by Wilkinson et al. [9], and there is rationale to suggest that laying hens are capable of selecting a balanced diet when offered a free choice of nutritionally complementary ingredients. Therefore, offering a separate dietary source of $\mathrm{Ca}$ in the form of limestone may preserve an optimal level of total Ca intake to support egg production and quality, albeit obtained partly from dietary $\mathrm{Ca}$ and partly from a limestone grit as a separate Ca source. Furthermore, if a specific appetite for Ca exists, the time interval between the consumption of supplementary limestone and consumption of the basal diet may contribute to better utilization of the nutrients contained in the basal diet. However, the ability for poultry to engage in dietary choice is complex and governed by various factors including social behavior, metabolic need, and various other environmental influences [10-12], which implies that the ability of hens to exploit feed choice may be limited, or at least not uniform.

The use of phytase to enhance the availability of phytate-bound minerals including Ca has been widely embraced in the broiler sector, although evidence for improvements in laying hen egg production is lacking and conflicting $[13,14]$. Nonetheless, phytase has been demonstrated to improve utilization of dietary Ca [14] and presumably enhance luminal Ca concentrations. As extracellular Ca sensing is suspected of being a factor in regulating appetite for nutrients by modulating taste perception [15], the effect of phytase on the ability of hens to modify supplementary Ca consumption is an area which merits investigation, as it may impact current feeding recommendations.

Therefore, the objective of this study was to evaluate the choice of feed and limestone grit intake, as well as the impact on egg quantity and quality characteristics of hens offered diets with varying dietary Ca concentrations and the inclusion of phytase.

\section{Materials and Methods}

\subsection{Ethics Statement}

The experimental procedures that were conducted in this study were approved by the University of Sydney Animal Ethics Committee (Project Number 2016/945) and were conducted in accordance with the Australian code for the care and use of animals for scientific purposes [16].

\subsection{Experimental Design, Protocol, and Animal Management}

A total of 144 ISA Brown hens (17 weeks of age) were housed individually within their cages measuring $25 \times 50 \times 50 \mathrm{~cm}$ with three adjacent cages forming a statistical unit. Hens were habituated to the cages and offered a common point of lay ration for two weeks before experimental treatments were assigned and measurements commenced (19 to 24 weeks of age). At 19 weeks, the rate of lay was $90 \%$. The photoperiod regimen was $16 \mathrm{~h}$ of light and $8 \mathrm{~h}$ of dark. Each trio of adjacent hens were randomly assigned to one of the six treatment groups, allowing for 8 replicates/treatment spaced randomly throughout the layer house. Diets based primarily on wheat, sorghum, and soybean meal 
and differing only in dietary $\mathrm{Ca}(40,30$, and $20 \mathrm{~g} / \mathrm{kg})$ and the inclusion or exclusion of phytase (RONOZYME HiPhos; 3500 FYT/kg diet; DSM Nutritional Products Australia Pty Ltd., East Wagga Wagga, Australia) were offered in mash form on an ad libitum basis for a duration of 6 weeks. The ingredient and nutrient compositions of the layer diets are shown in Tables 1 and 2. The dietary Ca source was primarily from a combination of fine and coarse ( 3-4 mm) limestone. The outlined nutrients met all recommended requirements of the ISA Brown laying hen in early lay [17]. All hens were offered ad libitum access to a limestone supplement (average diameter $3.4 \pm 1 \mathrm{~mm}$; analyzed $384 \mathrm{~g} \mathrm{Ca} / \mathrm{kg}$ ) supplied in an adjacent feeder. All hens were individually weighed at the beginning and end of the experiment using digital scales. Feed and limestone grit usage, and egg production data were collected on a weekly and daily basis, respectively, over the six-week period to calculate the average daily feed intake, limestone grit usage, and laying performance, egg weight, and feed-to-egg conversion ratio (FCR). Once a week, eggs were collected from one bird per trio for egg quality assessment.

Table 1. Ingredient composition of experimental diets (as fed).

\begin{tabular}{cccc}
\hline & \multicolumn{3}{c}{ Dietary Treatments } \\
\hline Calcium (g/kg Diet) & $\mathbf{4 0}$ & $\mathbf{3 0}$ & $\mathbf{2 0}$ \\
\hline Ingredients (g/kg) & & & 314 \\
Wheat & 208 & 261 & 244 \\
Soybean meal (48\% CP) & 266 & 255 & 9.5 \\
Soybean oil & 39 & 24 & 350 \\
Sorghum (9.2\% CP) & 350 & 350 & 47 \\
Limestone & 101 & 74 & 6.1 \\
Dicalcium phosphorus & 6.9 & 6.5 & 2.3 \\
Salt & 2.4 & 2.3 & 2.5 \\
Sodium bicarbonate & 2.5 & 2.5 & 1.1 \\
L-Lysine HCl & 0.8 & 1.0 & 2.1 \\
DL-Methionine & 2.2 & 2.1 & 0.3 \\
L-Tryptophan & 0.3 & 0.3 & 0.4 \\
Threonine & 0.3 & 0.3 & $(-/+)$ \\
Phytase ${ }^{1}$ & $(-/+)$ & $(-/+)$ & 1 \\
Layer premix ${ }^{2}$ & 1 & 1 & 20 \\
Celite & 20 & 20 & 1000
\end{tabular}

${ }^{1}$ DSM Nutritional Products Australia Pty Ltd; RONOZYME HiPhos 3500 FYT $/ \mathrm{kg}$ diet. ${ }^{2}$ Provided the following nutrients per kilogram of diet. vitamin A, $10000 \mathrm{IU}$; vitamin D, $2500 \mathrm{IU}$; vitamin E, $25 \mathrm{mg}$; vitamin K, $2.5 \mathrm{mg}$; thiamine, $2.5 \mathrm{mg}$; riboflavin, $5.0 \mathrm{mg}$; pyridoxine, $3.5 \mathrm{mg}$; vitamin B12, $0.015 \mathrm{mg}$; niacin, $30.0 \mathrm{mg}$; pantothenic acid, $9 \mathrm{mg}$; folic acid, $1.0 \mathrm{mg}$; biotin, $0.10 \mathrm{mg}$; Fe, $60.0 \mathrm{mg}$; Zn, $60.0 \mathrm{mg}$; Mn, $50.0 \mathrm{mg} ; \mathrm{Cu}, 5.0 \mathrm{mg}$; I, $1.0 \mathrm{mg}$; $\mathrm{Co}, 0.4 \mathrm{mg}$; Mo, $0.5 \mathrm{mg}$; Se, $0.2 \mathrm{mg}$; apo-ester, $2.9 \mathrm{mg}$; canthaxanthin, $3.1 \mathrm{mg}$; ethoxyquin, $25.0 \mathrm{mg}$ (Browning et al. 2015).

Table 2. Calculated and analyzed composition of experimental diets (as fed).

\begin{tabular}{ccccc}
\hline & & \multicolumn{3}{c}{ Dietary Treatments } \\
\hline Calcium $(\mathrm{g} / \mathrm{kg})$ & Units & $\mathbf{4 0}$ & $\mathbf{3 0}$ & $\mathbf{2 0}$ \\
\hline Phytase $(-/+)$ & & $(-/+)$ & $(-/+)$ & $(-/+)$ \\
\hline Calculated & & & & \\
\hline AME & $\mathrm{MJ} / \mathrm{kg}$ & 11.5 & 11.5 & 11.5 \\
Crude protein & $\mathrm{g} / \mathrm{kg}$ & 183 & 183 & 184 \\
(N $\times$ 6.25) & $\%$ & 2.1 & 2.1 & 2.2 \\
Crude fibre & $\mathrm{g} / \mathrm{kg}$ & 40.0 & 30.0 & 20.0 \\
Calcium & $\mathrm{g} / \mathrm{kg}$ & 4.8 & 4.8 & 4.8 \\
Phosphorus & $\mathrm{g} / \mathrm{kg}$ & 2.5 & 2.5 & 2.5 \\
npP & & & &
\end{tabular}


Table 2. Cont.

\begin{tabular}{ccccc}
\hline & & \multicolumn{3}{c}{ Dietary Treatments } \\
\hline Calcium (g/kg) & Units & $\mathbf{4 0}$ & $\mathbf{3 0}$ & $\mathbf{2 0}$ \\
\hline Calcium:npP & Ratio & 16.0 & 12.0 & 8.0 \\
Chloride & $\mathrm{g} / \mathrm{kg}$ & 2.0 & 2.0 & 2.0 \\
Sodium & $\mathrm{g} / \mathrm{kg}$ & 1.7 & 1.7 & 1.7 \\
TDC lysine & $\mathrm{g} / \mathrm{kg}$ & 8.5 & 8.5 & 8.5 \\
TDC methionine & $\mathrm{g} / \mathrm{kg}$ & 4.4 & 4.4 & 4.4 \\
TDC cysteine & $\mathrm{g} / \mathrm{kg}$ & 2.6 & 2.6 & 2.7 \\
TDC total sulfur amino acids & $\mathrm{g} / \mathrm{kg}$ & 7.0 & 7.0 & 7.1 \\
TDC threonine & $\mathrm{g} / \mathrm{kg}$ & 6 & 6 & 6 \\
TDC tryptophan & $\mathrm{g} / \mathrm{kg}$ & 1.9 & 1.9 & 1.9 \\
TDC valine & $\mathrm{g} / \mathrm{kg}$ & 7.7 & 7.7 & 7.7 \\
Analyzed & & & & \\
\hline Phytase FYT/kg $(-/+)$ & & $106 / 3588$ & $99 / 3436$ & $137 / 4061$ \\
Ca $(-/+$ phytase $)$ & $\mathrm{g} / \mathrm{kg}$ & $46.0 / 50.8$ & $33.4 / 33.2$ & $25.8 / 32.0$ \\
P & $\mathrm{g} / \mathrm{kg}$ & 4.6 & 4.8 & 4.8 \\
Crude protein & $\mathrm{g} / \mathrm{kg}$ & 19.9 & 19.6 & 20.3 \\
Gross Energy & $\mathrm{MJ} / \mathrm{kg}$ & 15.6 & 15.8 & 15.7 \\
Dry Matter & $\mathrm{g} / \mathrm{kg}$ & 91.0 & 90.7 & 90.4 \\
\hline
\end{tabular}

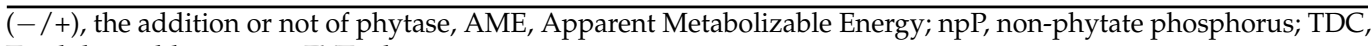
Total digestible content; FYT, phytase units.

\subsection{Egg Quality Assessment}

During the experimental period, egg quality analysis was conducted once weekly shortly after egg collection on the same day each week. Eggs were allowed to reach room temperature in the laboratory prior to the onset of measurements. Both internal and external egg quality parameters were measured and recorded. Egg weight (g), height $(\mathrm{mm})$, and width $(\mathrm{mm})$ were measured, using a digital scale for weight, to an accuracy of $0.01 \mathrm{~g}$, and a digital caliper (Kincrome, Sydney, Australia) for height and width. Egg height was measured as the length from pole to pole, while width was measured at the equator. Egg breaking force (peak force) was measured using a texture analyzer (TVT 6700 Texture Analyser Perten, Stockholm, Sweden). For internal egg quality testing, the breakout method was employed, using a flat, levelled glass surface on a metal stand with a reflective mirror. Yolk color was determined using a DSM Yolk Colour Fan (DSM, Switzerland), and assigned a value from 1 to 15 units. Using a digital caliper, albumen and yolk width were measured at their widest distance at a $90^{\circ}$ angle to each other. Albumen height was measured using a QCD AH reader (Technical Services and Supply Ltd., York, U.K.). Yolk height was measured using a digital height gauge (B.C. Ames Co., Waltham, MA, USA). Albumen and yolk were then separated using a plastic spatula and placed in weigh boats for weighing (g) purposes. Haugh values (1) were calculated using the formula:

$$
\text { Haugh unit }=100 \times \log \left(\mathrm{h}-1.7 \times \mathrm{w}^{0.37}+7.6\right)
$$

where $\mathrm{h}=$ height of the albumen in millimeters, $\mathrm{w}=$ egg weight in grams [18].

Eggshell weight was estimated by gently wiping residue albumen from shells with a paper towel and then air-drying for three days at room temperature. Once dried, eggshell weight was measured using digital scales to an accuracy of $0.01 \mathrm{~g}$. Egg shell thickness was measured at three egg segments (top, equator, and base) using a digital caliper (Kincrome, Sydney, Australia) and then averaged.

\subsection{Chemical Analysis of Diets, Limestone Supplement, and Excreta}

Total excreta were quantitatively collected from each cage, and feed intake was recorded for a $72 \mathrm{~h}$ collection period to determine the apparent metabolizable energy (AME) on a dry matter basis, nitrogen $(\mathrm{N})$ retention, and $\mathrm{N}$ corrected AME (AMEn). Diets, 
limestone supplement, and excreta were dried in a forced-air oven at $80^{\circ} \mathrm{C}$ for $24 \mathrm{~h}$, and the gross energy (GE) of feed and excreta output was determined using a Parr 1281 adiabatic bomb calorimeter (Parr Instrument Company, Moline, IL, USA) which was standardized with benzoic acid and used to determine AME (2) using the following calculation:

$$
\begin{gathered}
\mathrm{AME}_{\text {diet }}(\mathrm{MJ} / \mathrm{kg})=\left(\text { feed intake }(\mathrm{g} / \text { day }) \times \mathrm{GE}_{\text {diet }}(\mathrm{MJ} / \mathrm{kg})-(\text { excreta output }\right. \\
\left.(\mathrm{g} / \text { day }) \times \mathrm{GE}_{\text {excreta }}(\mathrm{MJ} / \mathrm{kg})\right) \div \text { feed intake }(\mathrm{g} / \text { day })
\end{gathered}
$$

The $\mathrm{N}$ content of diets and excreta was determined using an elemental analyzer (Leco Corporation, St Joseph, MI, USA), and N retention (3) was calculated from the following equation:

$$
\begin{aligned}
& \text { Coefficient of } \mathrm{N} \text { retention }=\left(\text { feed intake }(\mathrm{g} / \text { day }) \times \mathrm{N}_{\text {diet }}(\mathrm{g} / \mathrm{kg})\right)-(\text { excreta } \\
& \text { output } \left.(\mathrm{g} / \text { day }) \times \mathrm{N}_{\text {excreta }}(\mathrm{g} / \mathrm{kg})\right) \div\left(\text { feed intake }(\mathrm{g} / \text { day }) \times \mathrm{N}_{\text {diet }}(\mathrm{g} / \mathrm{kg})\right)
\end{aligned}
$$

AMEn $(\mathrm{MJ} / \mathrm{kg}$ ) values were calculated by correcting to zero $\mathrm{N}$ retention, using the factor of $36.54 \mathrm{~kJ} / \mathrm{g} \mathrm{N}$ retained in the body [19]. The retention of the dry matter (DM; 4) content of the combined intake of diets and the limestone grit was calculated using the following equation:

Coefficient of DM retention $=(D M$ intake of feed + grit $(g /$ day $))-(D M$ of excreta $(\mathrm{g} /$ day $)) \div($ DM intake of feed + grit $(\mathrm{g} /$ day $))$

The mineral composition of the feed, excreta, and limestone grit was determined by inductively coupled plasma optical emission spectrometry (ICP) using a PerkinElmer OPTIMA 7300 (PerkinElmer Inc., Waltham, MA, USA) following digestion with nitric acid and hydrogen peroxide beforehand. The coefficient of Ca retention for combined feed and limestone grit usage and for other feed minerals was calculated using the equations above.

\subsection{Statistical Analysis}

The data were analyzed as a $2 \times 3$ factorial arrangement of treatments using the GLM procedure of SAS [20]. The statistical model investigated the main effects of phytase inclusion, calcium concentration, and the associated two-way interactions. If there was a significant interaction, a Tukey's post analysis was done for multiple comparison. Mean values obtained from a trio of adjacent, individually caged hens served as the statistical replicate for feed intake and egg performance parameters, and eight of those replicates were investigated per treatment. For egg quality assessment and nutrient digestibility assays, one hen of each cage trio was randomly chosen and considered as one replicate. In addition, the lowest and highest $15 \%$ limestone users $(n=22)$ were selected regardless the treatment group for performance parameters comparison using the T-test procedure of SAS [20]. Initial bodyweight was evaluated as a covariate and retained in the model if significant. Statistical differences were reported as significant if $p<0.05,<0.01$, and $<0.001$. The development of limestone grit usage, egg weight, rate of lay, and feed intake over time was assessed by repeated measures using the R studio software (v1.3.959; Rstudio, Boston, MA, USA) with the package "rstatix" [21]. Limestone grit usage data was log-transformed prior to statistical analysis.

\section{Results}

\subsection{Dietary Composition}

The dietary ingredients and calculated and analyzed composition are presented in Tables 1 and 2. The analyzed Ca content (as is basis) was $48.4( \pm 3.23), 33.3( \pm 2.53)$, and $28.9( \pm 3.78) \mathrm{g} / \mathrm{kg}$ for the $40 \mathrm{~g} / \mathrm{kg}$ dietary Ca, $30 \mathrm{~g} / \mathrm{kg}$ dietary Ca, and $20 \mathrm{~g} / \mathrm{kg}$ dietary Ca treatments, respectively. The average phytase content was 114 and $3695 \mathrm{FYT} / \mathrm{kg}$ for the control and phytase-supplemented diets, respectively. The Ca content of limestone grit was $384 \mathrm{~g} / \mathrm{kg}$. 


\subsection{Bird Performance and Egg Quality Measurements}

The response of bodyweight measurements, feed intake, egg output, and feed efficiency to dietary treatments are presented in Table 3 and Figures 1-3. There was no difference in bodyweight between treatment groups at the onset of the study. Birds offered the $40 \mathrm{~g} / \mathrm{kg}$ and $30 \mathrm{~g} / \mathrm{kg}$ dietary Ca treatments had a greater proportional bodyweight increase and hence a greater final body weight when compared with those of the $20 \mathrm{~g} / \mathrm{kg}$ Ca diets $(p=0.004)$. Daily feed intake did not differ between treatment groups. However, there was an interaction between phytase and dietary Ca concentrations on calculated daily Ca intake from feed. Daily Ca intake from feed was significantly greater in the $20 \mathrm{~g} / \mathrm{kg}$ dietary Ca treatment groups supplemented with phytase when compared with complementary Ca diets containing no phytase $(p=0.007)$. However, there was no effect of phytase on daily $\mathrm{Ca}$ intake from the $40 / \mathrm{g} / \mathrm{kg}$ and $30 \mathrm{~g} / \mathrm{kg}$ dietary Ca group. These differences reflect the measured differences in dietary Ca between phytase inclusion at each Ca level. The overall response of limestone grit intake to dietary treatments is presented in Table 3, and the weekly consumption is presented in Figure 1. Limestone grit usage was affected by dietary phytase inclusion, with birds offered dietary phytase consuming less of the limestone grit when compared with the non-supplemented diets $(p=0.024)$. This effect was the most pronounced in the $40 \mathrm{~g} / \mathrm{kg}$ Ca diets. The combined intake of Ca from the diet and the limestone grit was affected by dietary Ca level, whereby hens offered the $40 \mathrm{~g} / \mathrm{kg}$ Ca diets had the greatest total Ca intake, followed by those of the $30 \mathrm{~g} / \mathrm{kg}$ Ca diets and then the $20 \mathrm{~g} / \mathrm{kg}$ Ca diets. Phytase inclusion had no effect on total Ca intake. Egg weight, egg mass, and FCR were unaffected by dietary treatments. Overall rate of lay was unaffected by dietary treatment. However, when assessed on a weekly basis, the effect of phytase on laying performance differed among Ca intake groups, where hens which were fed with $40 \mathrm{~g} / \mathrm{kg} \mathrm{Ca}$ and no phytase experienced a higher laying rate (Figure 2).

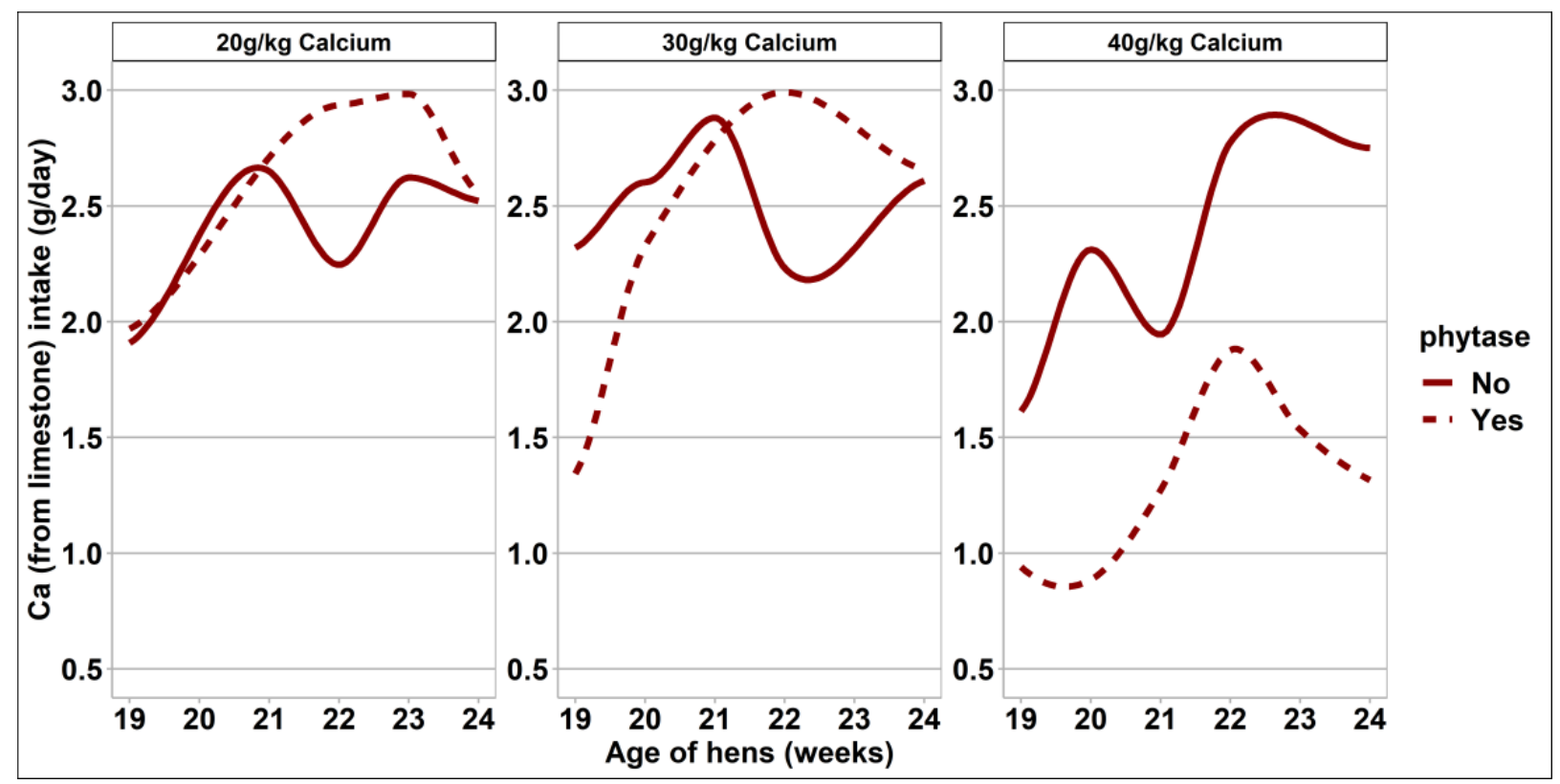

Figure 1. Trendlines of the estimated Ca intake from limestone (grams/hen/day) of hens offered a choice of limestone grit throughout the 6-week experimental period. The data were log-transformed prior to statistical analysis. The data presented here were back-transformed for meaningful visualization $(n=48)$. 
Table 3. Effect of differing calcium levels and addition of phytase on bodyweight and feed intake of laying hens (19-24 weeks of age).

\begin{tabular}{|c|c|c|c|c|c|c|c|c|c|c|c|c|}
\hline $\begin{array}{l}\text { Calcium } \\
\text { (g/kg) }\end{array}$ & Phytase & $\begin{array}{c}\text { Initial } \\
\text { Body } \\
\text { Weight (g) }\end{array}$ & $\begin{array}{l}\text { Final Body } \\
\text { Weight (g) }\end{array}$ & $\begin{array}{l}\text { Body Weight } \\
\text { Change (\%) }\end{array}$ & $\begin{array}{c}\text { Feed } \\
\text { Intake } \\
\text { (g/day) }\end{array}$ & $\begin{array}{l}\text { Ca Intake } \\
\text { (from Feed, } \\
\text { g/hen/day) }\end{array}$ & $\begin{array}{l}\text { Ca Intake from } \\
\text { Limestone } \\
\text { (g/hen/day) }\end{array}$ & $\begin{array}{l}\text { Total Ca } \\
\text { Intake }\end{array}$ & $\begin{array}{c}\text { Rate of Lay } \\
(\%)\end{array}$ & $\begin{array}{l}\text { Egg Weight } \\
\text { (g/hen/day) }\end{array}$ & $\begin{array}{l}\text { Egg Mass } \\
\text { (g/hen/day) }\end{array}$ & FCR \\
\hline 40 & - & 1890 & 1952 & 3.29 & 118 & $5.43^{\mathrm{a}}$ & 2.45 & 7.88 & 98 & 62 & 61 & 1.947 \\
\hline 30 & - & 1857 & 1924 & 3.66 & 117 & $3.91^{\mathrm{c}}$ & 2.54 & 6.45 & 98 & 62 & 61 & 1.918 \\
\hline 30 & + & 1893 & 1936 & 2.27 & 120 & $3.99^{c}$ & 2.50 & 6.49 & 98 & 63 & 61 & 1.963 \\
\hline 20 & - & 1854 & 1859 & 0.27 & 116 & $2.97^{\mathrm{d}}$ & 2.81 & 5.78 & 98 & 61 & 60 & 1.940 \\
\hline 20 & + & 1862 & 1881 & 1.02 & 116 & $3.72^{c}$ & 2.61 & 6.33 & 97 & 60 & 59 & 1.980 \\
\hline 40 & & 1874 & $1941^{\mathrm{a}}$ & $3.61^{\mathrm{a}}$ & 117 & 5.68 & 1.85 & $7.53^{a}$ & 97 & 62 & 60 & 1.95 \\
\hline 30 & & 1875 & $1930^{\mathrm{a}}$ & $2.97^{\mathrm{a}}$ & 119 & 3.95 & 2.52 & $6.47^{\mathrm{ab}}$ & 98 & 63 & 61 & 1.94 \\
\hline 20 & & 1858 & $1870^{\mathrm{b}}$ & $0.64^{b}$ & 116 & 3.34 & 2.71 & $6.06^{\mathrm{b}}$ & 98 & 61 & 59 & 1.96 \\
\hline \multirow[t]{3}{*}{ SEM } & & 17 & 18 & 0.62 & 1.68 & 0.070 & 0.392 & 0.391 & 0.498 & 0.616 & 0.616 & 0.028 \\
\hline & - & 1867 & 1911 & 2.40 & 117 & 4.10 & 2.60 & 6.70 & 98 & 62 & 61 & 1.93 \\
\hline & + & 1871 & 1916 & 2.41 & 118 & 4.55 & 2.12 & 6.67 & 97 & 62 & 60 & 1.97 \\
\hline SEM & & 13 & 14 & 0.503 & 1.37 & 0.057 & 0.320 & 0.320 & 0.407 & 0.503 & 0.503 & 0.02 \\
\hline \multicolumn{13}{|l|}{$p$-values } \\
\hline $\mathrm{Ca}$ & & 0.725 & 0.014 & 0.004 & 0.599 & 0.001 & 0.196 & 0.031 & 0.590 & 0.128 & 0.105 & 0.886 \\
\hline Interaction & & 0.349 & 0.657 & 0.393 & 0.635 & 0.007 & 0.275 & 0.532 & 0.603 & 0.706 & 0.670 & 0.886 \\
\hline
\end{tabular}

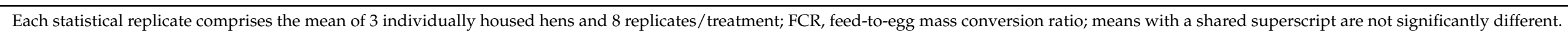




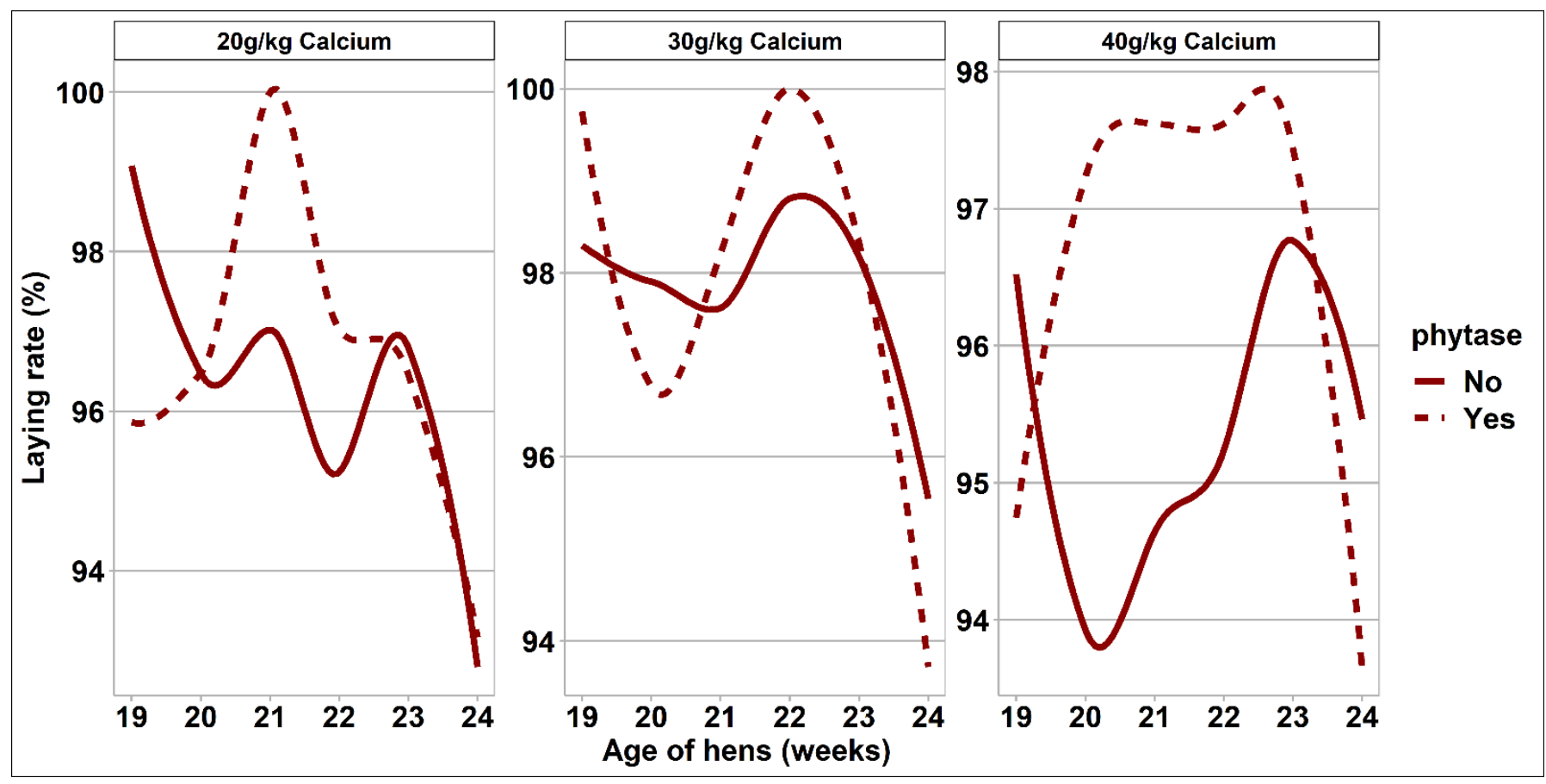

Figure 2. Trendlines visualizing the laying rate that hens of different dietary treatments experienced during the 6-week experimental period $(n=48)$.

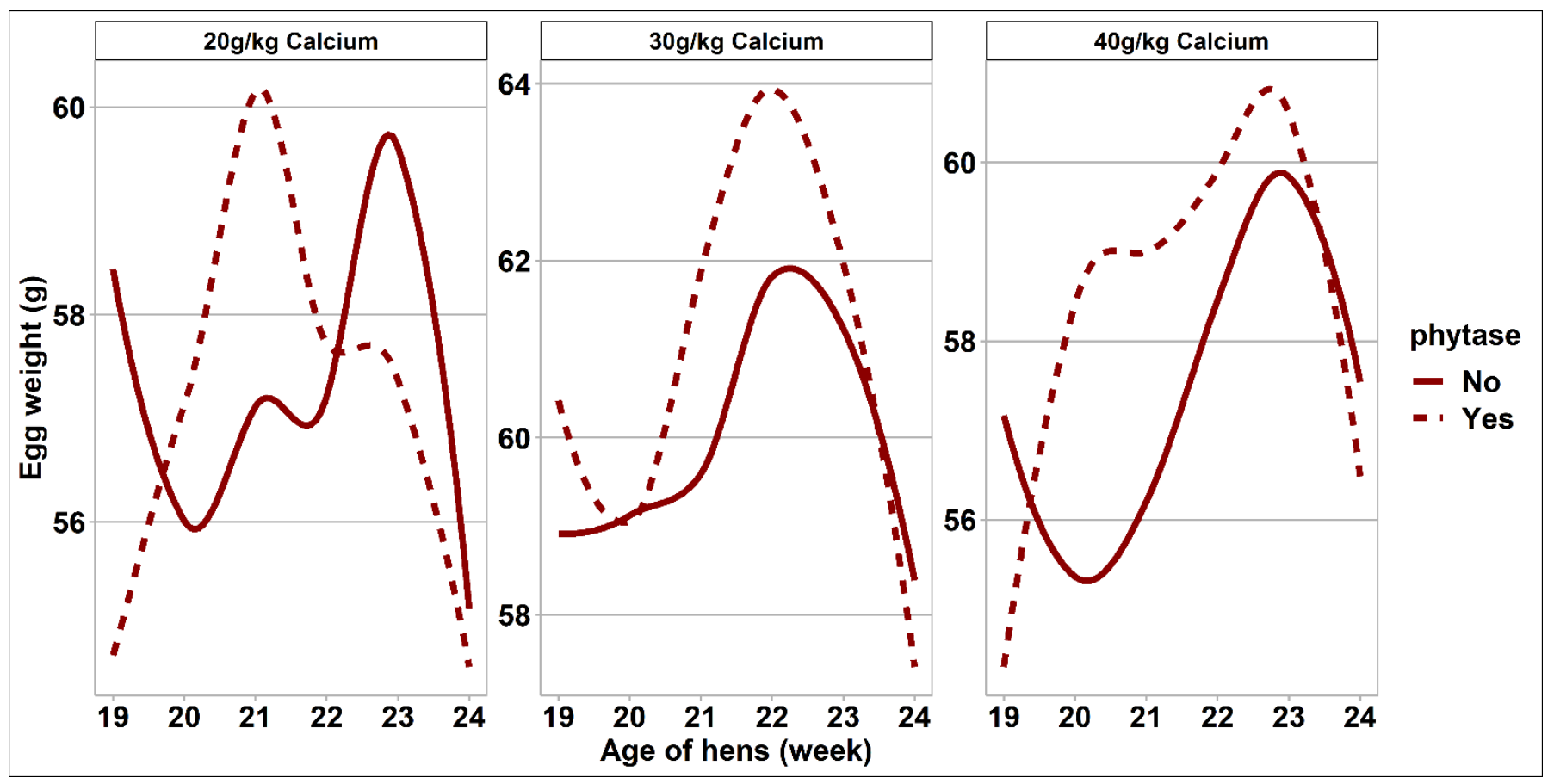

Figure 3. Trendlines visualize the impact and interaction of the calcium level and phytase inclusion of the diet on egg weight during the 6-week experimental period $(n=48)$. 
To clarify the role of limestone consumption on intake and egg production parameters, the hens were ranked on the basis of whether they were high or low limestone consumers (regardless of dietary treatment group) and compared (Table 4). Initial bodyweight, rate of lay, and egg mass was significantly higher, and dietary Ca intake was lower in the $15 \%$ highest limestone intake hens compared to those of the $15 \%$ with the least limestone intake.

Table 4. Comparison of the performance data of the extreme $15 \%$ of hens ranked as high or low on limestone grit intake, regardless the treatment groups.

\begin{tabular}{ccccc}
\hline Variable & $\begin{array}{c}\text { Low Limestone Grit } \\
\text { Intake }(\boldsymbol{n = 2 2 )}\end{array}$ & $\begin{array}{c}\text { High Limestone Grit } \\
\text { Intake }(\boldsymbol{n}=\mathbf{2 2})\end{array}$ & SEM & $\boldsymbol{p}$-Value \\
\hline Limestone grit intake (g/day) & $0.039(0.013)$ & $6.97(1.14)$ & - & - \\
Initial body weight (g) & 1841 & 1913 & 23.5 & 0.038 \\
Final body weight (g) & 1920 & 1911 & 18.9 & 0.744 \\
Feed intake (g/hen/day) & 114 & 114 & 0.226 & 1.52 \\
Ca intake (from feed, g/hen/day) & 4.57 & 3.91 & 1.34 & 0.043 \\
Rate of lay (\%) & 91 & 97 & 1.87 & 0.024 \\
Egg weight (g/hen/day) & 57 & 51 & 0.036 & 0.030 \\
Egg mass (g/hen/day) & 53 & 1.94 & 0.182 \\
FCR & 2.01 & 59 & 0.036 \\
\hline
\end{tabular}

Twenty-two individual hens selected with the highest and lowest individual limestone grit intake were used for this analysis. ${ }^{*}$ The number in brackets refers to the standard deviation.

The response of egg quality measurements to dietary treatments is presented in Table 5. There was no interaction between phytase and Ca concentrations or a main effect of phytase on egg measurements. To further investigate the impact of phytase intake on egg weight separately for each Ca intake group and during the onset of lay, Figure 3 visualizes the (non-significant) interaction using trendlines. Overall, egg weight, yolk weight, and shell weight were the greatest in eggs obtained from hens fed the $40 \mathrm{~g} / \mathrm{kg}$ Ca diets, which was statistically significant when compared to those of eggs obtained from hens fed the $20 \mathrm{~g} / \mathrm{kg}$ Ca diet ( $p=0.030, p=0.010$, and $p=0.001$, respectively). Similarly, the yolk color and eggshell breaking force was the greatest for eggs obtained from hens fed the $40 \mathrm{~g} / \mathrm{kg} \mathrm{Ca}$ diets and statistically significantly different when being compared to those of eggs obtained from hens fed the $20 \mathrm{~g} / \mathrm{kg}$ Ca diets ( $p=0.002$ and $p=0.010$, respectively). Shell thickness was the greatest for eggs obtained from hens fed the $40 \mathrm{~g} / \mathrm{kg}$ Ca diets, intermediate and significantly different for the eggs obtained from hens fed $30 \mathrm{~g} / \mathrm{kg}$ Ca diets, and thinnest for the eggs obtained from hens fed $20 \mathrm{~g} / \mathrm{kg}$ Ca diets (all $p=0.001$ ). 
Table 5. Effect of differing Ca levels and addition of phytase on egg quality of laying hens (19-24 weeks of age).

\begin{tabular}{|c|c|c|c|c|c|c|c|c|c|c|c|c|}
\hline Calcium & Phytase & $\begin{array}{c}\text { Egg } \\
\text { Weight (g) }\end{array}$ & $\begin{array}{c}\text { Albumen } \\
\text { Height (mm) }\end{array}$ & $\begin{array}{l}\text { Albumen } \\
\text { Weight (g) }\end{array}$ & $\begin{array}{c}\text { Haugh } \\
\text { Unit }\end{array}$ & $\begin{array}{l}\text { Yolk Height } \\
\text { (mm) }\end{array}$ & $\begin{array}{c}\text { Yolk } \\
\text { Weight (g) }\end{array}$ & $\begin{array}{l}\text { Yolk } \\
\text { Color }\end{array}$ & $\begin{array}{l}\text { Egg Breaking } \\
\text { Force }(\mathrm{g})\end{array}$ & $\begin{array}{c}\text { Shell } \\
\text { Weight (g) }\end{array}$ & $\begin{array}{c}\text { Shell } \\
\text { Weight (\%) }\end{array}$ & $\begin{array}{c}\text { Shell Thickness } \\
(\mathrm{mm})\end{array}$ \\
\hline 40 & - & 63.5 & 9.8 & 37.9 & 98 & 16.9 & 15.4 & 11.8 & 4667 & 6.62 & 10.4 & 0.401 \\
\hline 40 & + & 64.2 & 10.4 & 39.2 & 100 & 17.3 & 15.4 & 11.7 & 4781 & 6.78 & 10.5 & 0.406 \\
\hline 20 & + & 64.3 & 9.6 & 38.7 & 96 & 16.3 & 15.3 & 11.6 & 4448 & 6.32 & 9.9 & 0.384 \\
\hline 30 & - & 60.9 & 9.8 & 37.3 & 98 & 17.1 & 14.9 & 10.9 & 4203 & 5.80 & 9.4 & 0.340 \\
\hline 30 & + & 59.3 & 9.6 & 35.3 & 97 & 18.4 & 14.3 & 11.1 & 4246 & 5.74 & 9.7 & 0.337 \\
\hline SEM & & 1.13 & 0.40 & 0.97 & 1.79 & 0.629 & 0.269 & 0.180 & 170 & 0.17 & 0.26 & 0.01 \\
\hline 30 & & $63.3^{\mathrm{a}}$ & 9.64 & 38.1 & 96.9 & 16.7 & $15.1^{\mathrm{a}}$ & $11.4^{\mathrm{a}}$ & $4460^{\mathrm{ab}}$ & $6.41^{\mathrm{a}}$ & $10.2^{\mathrm{a}}$ & $0.386^{\mathrm{b}}$ \\
\hline 20 & & $60.1^{b}$ & 9.70 & 36.3 & 97.7 & 17.7 & $14.6^{\mathrm{b}}$ & $11.0^{\mathrm{b}}$ & $4224^{b}$ & $5.77^{b}$ & $9.6^{b}$ & $0.339^{c}$ \\
\hline \multirow[t]{3}{*}{ SEM } & & 0.796 & 0.282 & 0.684 & 1.270 & 0.445 & 0.190 & 0.128 & 121 & 0.123 & 0.181 & 0.004 \\
\hline & - & 62.3 & 9.79 & 37.6 & 97.7 & 17.1 & 15.1 & 11.3 & 4442 & 6.31 & 6.31 & 0.376 \\
\hline & + & 62.6 & 9.85 & 37.7 & 98.0 & 17.3 & 15.0 & 11.5 & 4495 & 6.29 & 6.28 & 0.376 \\
\hline SEM & & 0.650 & 0.231 & 0.559 & 1.03 & 0.34 & 0.13 & 0.10 & 97.9 & 0.09 & 0.100 & 0.003 \\
\hline \multicolumn{13}{|l|}{$p$-values } \\
\hline $\mathrm{Ca}$ & & 0.003 & 0.449 & 0.053 & 0.555 & 0.260 & 0.010 & 0.002 & 0.010 & 0.001 & 0.006 & 0.001 \\
\hline Phytase & & 0.735 & 0.861 & 0.883 & 0.842 & 0.568 & 0.784 & 0.279 & 0.705 & 0.874 & 0.866 & 0.892 \\
\hline
\end{tabular}

Means with a shared superscript are not significantly different. 


\subsection{Nutrient Digestibility and Retention}

The response of measurements of digestibility and nutrient retention are presented in Tables 6 and 7. There was no effect of dietary treatments on estimates of AME, AMEn, and nitrogen retention. There was a tendency for an interaction between phytase and Ca concentrations on dry matter retention $(p=0.084)$. The addition of phytase to the $40 \mathrm{~g} / \mathrm{kg}$ dietary Ca increased the coefficient of dry matter retention by $14 \%$. This response to phytase was not observed in the $30 \mathrm{~g} / \mathrm{kg}$ and $20 \mathrm{~g} / \mathrm{kg}$ Ca diets. There was an interaction between dietary $\mathrm{Ca}$ concentrations and phytase inclusion on Ca retention. Ca retention was lower in the $30 \mathrm{~g} / \mathrm{kg}$ Ca diet containing phytase when compared with that in the $30 \mathrm{~g} / \mathrm{kg}$ Ca diet without phytase. The retention of Ca was greater but not significantly different in the $40 \mathrm{~g} / \mathrm{kg}$ Ca diet containing phytase when compared to that of the same Ca concentration diet without phytase. There was no effect of phytase on Ca retention on hens offered the $20 \mathrm{~g} / \mathrm{kg}$ Ca diets. There was an interaction between phytase inclusion and dietary $\mathrm{Ca}$ concentrations on $\mathrm{Cu}$ retention. The retention of $\mathrm{Cu}$ was greater for the hens offered the $30 \mathrm{~g} / \mathrm{kg}$ Ca diet and phytase when compared with that of hens fed the $30 \mathrm{~g} / \mathrm{kg}$ Ca diet without phytase. However, there was no effect of phytase supplementation on $\mathrm{Cu}$ retention at other dietary $\mathrm{Ca}$ concentrations. There was an interaction between dietary $\mathrm{Ca}$ concentrations and phytase for $\mathrm{K}$ retention. $\mathrm{K}$ retention was higher for birds offered the $40 \mathrm{~g} / \mathrm{kg}$ Ca diet and phytase when compared with the that of birds fed the same Ca concentration diet containing no phytase. However, there was no effect of phytase supplementation on $\mathrm{K}$ retention of hens offered the $30 \mathrm{~g} / \mathrm{kg}$ and $20 \mathrm{~g} / \mathrm{kg}$ Ca diets. Finally, there was a significant effect of dietary $\mathrm{Ca}$ concentrations on Fe retention. Fe retention was the greatest for the $20 \mathrm{~g} / \mathrm{kg}$ Ca diet, intermediate and not different for the $40 \mathrm{~g} / \mathrm{kg}$ Ca diet, and lowest for the $30 \mathrm{~g} / \mathrm{kg}$ Ca diet $(p<0.05)$.

Table 6. Effect of dietary Ca concentrations and addition of phytase on measurements of digestibility and retention.

\begin{tabular}{cccccc}
\hline Ca $(\mathbf{g} / \mathbf{k g})$ & Phytase & AME & AMEn & N Retention & Dry Matter Retention \\
\hline 40 & - & 13.5 & 13.4 & 0.535 & 0.648 \\
40 & + & 13.5 & 13.3 & 0.527 & 0.739 \\
30 & - & 13.7 & 13.6 & 0.501 & 0.731 \\
30 & + & 13.7 & 13.6 & 0.530 & 0.695 \\
20 & - & 13.6 & 13.5 & 0.577 & 0.704 \\
20 & + & 13.5 & 13.4 & 0.587 & 0.697 \\
SEM & & 0.304 & 0.296 & 0.038 & 0.029 \\
40 & & 13.5 & 13.4 & 0.531 & 0.694 \\
30 & & 13.7 & 13.6 & 0.515 & 0.713 \\
20 & & 13.6 & 13.4 & 0.582 & 0.700 \\
SEM & & 0.215 & 0.210 & 0.027 & 0.020 \\
& - & 13.6 & 13.5 & 0.538 & 0.694 \\
SEM & + & 13.6 & 13.4 & 0.548 & 0.710 \\
$p-$ values & & 0.176 & 0.171 & 0.250 & 0.017 \\
Ca & & & & & 0.789 \\
Phytase & & 0.785 & 0.763 & 0.189 & 0.495 \\
Interaction & & 0.831 & 0.793 & 0.744 & 0.084 \\
\hline AME/n, apparent metabolizable energy/corrected for nitrogen retention; &
\end{tabular}

$\overline{\mathrm{AME}} \mathrm{n}$, apparent metabolizable energy/corrected for nitrogen retention; N, nitrogen. 
Table 7. The impact of different dietary Ca levels, phytase, and limestone consumption on measurements of macro and micro mineral retention.

\begin{tabular}{|c|c|c|c|c|c|c|c|c|c|}
\hline Ca (g/kg) & Phytase & $\mathrm{Na}$ & $\mathrm{Ca}$ & $\mathbf{P}$ & $\mathrm{Cu}$ & $\mathrm{Fe}$ & Mg & $\mathbf{K}$ & Mn \\
\hline 40 & - & 0.666 & 0.529 ac & 0.447 & $0.334^{c}$ & 0.350 & 0.209 & $0.304^{\mathrm{ab}}$ & 0.143 \\
\hline 40 & + & 0.710 & $0.740^{a b c}$ & 0.363 & $0.239 \mathrm{bc}$ & 0.517 & 0.399 & $0.435^{c}$ & 0.386 \\
\hline 30 & - & 0.694 & $0.777^{a b}$ & 0.357 & $0.060^{b}$ & 0.434 & 0.402 & $0.308^{a b}$ & 0.182 \\
\hline 30 & + & 0.664 & $0.551^{\mathrm{c}}$ & 0.232 & $0.338^{c}$ & 0.364 & 0.338 & $0.279^{b}$ & 0.192 \\
\hline 20 & - & 0.674 & $0.849^{b}$ & 0.406 & $0.378^{\mathrm{ac}}$ & 0.537 & 0.349 & $0.405^{\mathrm{ac}}$ & 0.313 \\
\hline 20 & + & 0.689 & $0.821^{b}$ & 0.389 & $0.497^{\mathrm{a}}$ & 0.486 & 0.406 & $0.363^{a b c}$ & 0.319 \\
\hline SEM & & 0.024 & 0.085 & 0.057 & 0.053 & 0.072 & 0.079 & 0.037 & 0.055 \\
\hline 40 & & 0.688 & 0.634 & 0.405 & 0.286 & 0.433 & 0.304 & 0.369 & 0.265 \\
\hline 30 & & 0.679 & 0.664 & 0.294 & 0.199 & 0.399 & 0.370 & 0.294 & 0.187 \\
\hline 20 & & 0.682 & 0.835 & 0.398 & 0.438 & 0.511 & 0.377 & 0.384 & 0.316 \\
\hline \multirow[t]{3}{*}{ SEM } & & 0.017 & 0.060 & 0.041 & 0.038 & 0.051 & 0.056 & 0.026 & 0.040 \\
\hline & - & 0.678 & 0.718 & 0.403 & 0.257 & 0.440 & 0.320 & 0.339 & 0.213 \\
\hline & + & 0.688 & 0.704 & 0.328 & 0.358 & 0.456 & 0.381 & 0.359 & 0.299 \\
\hline SEM & & 0.014 & 0.049 & 0.033 & 0.031 & 0.042 & 0.046 & 0.021 & 0.032 \\
\hline \multicolumn{10}{|l|}{$p$-values } \\
\hline $\mathrm{Ca}$ & & 0.919 & 0.064 & 0.130 & 0.001 & 0.285 & 0.595 & 0.038 & 0.093 \\
\hline Phytase & & 0.611 & 0.840 & 0.117 & 0.029 & 0.790 & 0.355 & 0.515 & 0.072 \\
\hline Interaction & & 0.301 & 0.044 & 0.645 & 0.007 & 0.222 & 0.289 & 0.045 & 0.071 \\
\hline
\end{tabular}

$\mathrm{Ca}$, calcium; $\mathrm{Na}$, sodium; $\mathrm{P}$, phosphorus; $\mathrm{Cu}$, copper; $\mathrm{S}$, sulfur; $\mathrm{Fe}$, iron; $\mathrm{Mg}$, magnesium; $\mathrm{K}$, potassium; Mn, manganese. Means with a shared superscript are not significantly different.

\section{Discussion}

A hypothesis of this study was that reducing dietary $\mathrm{Ca}$ and providing supplementary limestone grit may preserve overall $\mathrm{Ca}$ intake but with some additional benefits in performance and nutrient retention. The guidelines around Ca nutrition for ISA Brown hens in early lay suggests an ideal concentration of $40-41 \mathrm{~g} \mathrm{Ca} / \mathrm{kg}$ diet with an expected feed intake of between 114-115 g/hen/day, giving an estimated Ca intake of approximately $4.6 \mathrm{~g}$ of $\mathrm{Ca} /$ hen/day [17]. In this study, all treatment groups exceeded that threshold with hens assigned to the $40 \mathrm{~g} / \mathrm{kg}$ Ca diets having the highest Ca consumption. Based on these observations, it seems reasonable to assume that Ca intake was adequate for the $20 \mathrm{~g} / \mathrm{kg}$ dietary Ca group and in line with the intake target for the breed. However, habituation to limestone usage was highly variable; for approximately $40 \%$ of the hens, disappearance of limestone grit was less than $1 \mathrm{~g} / \mathrm{hen} /$ day. In contrast, the top $15 \%$ of birds when ranked in terms of greatest limestone intake utilized approximately $7 \mathrm{~g} /$ hen/day across all treatments. Habituation of an animal to a feeding practice is a behavior which may be influenced by the actions of other animals within the group $[10,22,23]$. In this study, the hens were housed individually in wire cages with two dedicated feeders per cage. While a degree of auditory and visual contact was maintained throughout the study, it is unclear how these housing conditions may have impacted the capacity for competitive feeding behavior and can only be speculated [9]. The hens used in this study were at the very early stages of lay, and while the rate of lay was close to the maximum at $97 \%$, bone calcium reserves would be replete at the onset of lay and shortly thereafter [24], which may account for the variable adoption of limestone grit consumption. Feed intake was comparable between groups regardless of Ca concentration or dietary phytase. Phytase inclusion reduced limestone grit usage, and this was particularly pronounced in the hens offered the $40 \mathrm{~g} / \mathrm{kg}$ Ca diets, where phytase addition resulted in a $49 \%$ decrease in grit consumption. Furthermore, this effect of phytase in the highest dietary Ca treatment group was evident from the onset of the study (Figure 2), supporting the theory that Ca appetite specifically may be influenced by the physiological Ca status of the hen as governed by whole body reserves and the quantities of $\mathrm{Ca}$ that are available in the digestive tract. The ratio of $\mathrm{Ca} /$ phytate was highest in these treatment groups, and releasing this phytate-bound Ca would likely have consequences for Ca-specific appetite. Holcombe et al. [7] reported how 37-week-old layers were able 
to discriminate between a choice of a Ca-deficient and a Ca-replete diet in order to satisfy metabolic requirements. To account for some of the variability between individuals around limestone grit intake usage, the birds were ranked on the basis of limestone grit intake regardless of dietary assignment. The hens which were ranked as high consumers of the limestone grit consumed 17\% less dietary $\mathrm{Ca}$ from the basal diet and were heavier from the onset of the study, had a higher rate of lay, a tendency for heavier eggs, and hence a markedly higher egg mass compared with those of the hens ranked as consuming low levels of limestone grit. Extrapolating from these findings, the present study would suggest that some hens were able to redress suboptimal dietary Ca intake with greater utility of a supplementary limestone source, but this nutrient-specific appetite was not uniform.

Egg production variables such as egg weight, egg mass, rate of lay, and FCR were unaffected by dietary treatments. This suggests that the supplementary limestone consumed in the lower Ca diets preserved these variables. However, caution needs to be exercised in speculating here, as the study focused on early lay birds and only for a sixweek period. The hens assigned to the $20 \mathrm{~g} / \mathrm{kg}$ Ca diets had a lower final body weight. This suggests that these hens were possibly compensating for the undersupply of dietary Ca relative to the other Ca diet groups. Similarly, Ziaei et al. [25] reported that laying hens with reduced calcium intake experienced a reduction in body weight. By using hens at the beginning of lay, the skeletal frame of the average hen would have just finished its development, and providing $20 \mathrm{~g} / \mathrm{kg}$ of calcium to those individuals might not have been sufficient to promote optimal growth and health [26]. The lower intake of coarse limestone particles from the basal diet might have further compromised nutrient uptake, as coarse feed particles are known to increase organ, especially gizzard, development and benefit nutrient digestibility and uptake via increased intestinal microstructure and transport capacity $[27,28]$. In contrast, Jiang et al. [5] reported no negative impact on performance variables when 19-week-old layers were fed a $26 \mathrm{~g} / \mathrm{kg}$ Ca diet, indicating that the $20 \mathrm{~g} / \mathrm{kg}$ diet fed in the present study might have been just below the minimum requirement and supported an unfavorable $\mathrm{Ca} / \mathrm{P}$ ratio, regardless of the complementary limestone intake, possibly affecting skeletal Ca metabolism.

Egg quality variables and particularly those related to shell strength and weight were negatively impacted in birds offered the $20 \mathrm{~g} / \mathrm{kg}$ Ca diets when compared to those of eggs obtained from hens fed the $40 \mathrm{~g} / \mathrm{kg}$ Ca diets and, occasionally, eggs obtained from hens fed the $30 \mathrm{~g} / \mathrm{kg}$ Ca diet. This indicates that even with supplementary limestone grit provision, maintaining adequate $\mathrm{Ca}$ intake from the basal diet is still an important objective, particularly when the variability in limestone grit consumption between hens as observed in this experiment is considered. While there was an impact of superdosing with phytase on limestone grit consumption, particularly in the $40 \mathrm{~g} / \mathrm{kg}$ Ca diet, there was no impact of adding the enzyme on hen body weight gain or any other investigated production parameters. In this study, the levels of non-phytate phosphorus were replete for ISA Browns in early lay, and this may explain the absence of an effect of phytase in improving production parameters. However, Kim et al., [29] reported an improvement in egg production rate of lay, but not for other variables in hens superdosed with phytase at dietary npP levels comparable with those of this study. In contrast, other authors have reported improvements in egg production in response to phytase inclusion, which seems dependent on conditions such as suboptimal non-phytate phosphorus supply [30]. While the level of npP was suitable for all dietary groups, the decreasing Ca concentrations led to a decline in egg productivity and egg quality in the $20 \mathrm{~g} / \mathrm{kg}$ group, and there is no evidence to indicate that the addition of phytase improved performance in this treatment group in this study. In this group, the lower $\mathrm{Ca} / \mathrm{npP}$ would be favorable for maximum digestion of both $\mathrm{Ca}$ and $\mathrm{P}$, and it therefore seems likely that phytase would be of limited benefit with total dietary Ca supply being the limiting factor.

The inclusion of phytase significantly increased Ca retention in the $40 \mathrm{~g} / \mathrm{kg}$ Ca diets from 0.529 to 0.740 . However, it reduced or did not affect Ca retention in the 30 and $20 \mathrm{~g} / \mathrm{kg}$ Ca diets. A similar outcome was observed for the retention of dietary $\mathrm{K}$. These interactions 
are difficult to account for, but nonetheless raise some interesting questions into how high Ca intake and greater Ca bioavailability as effected by phytase may affect voluntary usage of a supplementary limestone grit in laying hens. The review of Selle et al. [4] discussed how higher molar ratios of $\mathrm{Ca}$ /phytate-P can result in highly insoluble Ca-phytate complexes which are recalcitrant to enzymatic degradation by phytase. However, in that same review, the findings of Driver et al. [30] were covered, who found that phytase yielded a greater benefit in broilers offered a higher $\mathrm{Ca}$ /phytate-P ratio. The response to phytase in laying hens is clearly a topic which merits further study for both its role in nutrient and energy availability and in influencing appetite and feeding behavior. For the retention of other minerals such as $\mathrm{Fe}$ and $\mathrm{Cu}$, there were main effects of dietary $\mathrm{Ca}$ and an interaction between $\mathrm{Ca}$ and phytase, respectively, but the relevance these changes hold for production variables are difficult to unite. Further studies evaluating small intestinal absorption rates may be merited under similar dietary conditions.

\section{Conclusions}

In conclusion, egg production variables were not impacted by lowering dietary $\mathrm{Ca}$ level or the addition of phytase in early lay hens offered an additional limestone source. The results of the present study showed that overall limestone grit consumption was not uniform across laying hens. Hence, hens fed the 20 and $30 \mathrm{~g} / \mathrm{kg}$ Ca diet were not able to compensate $\mathrm{Ca}$ intake adequately using the supplementary limestone, resulting in inferior egg quality. In addition, the inclusion of phytase did not impact any investigated performance parameters but decreased limestone intake in hens fed the $40 \mathrm{~g} / \mathrm{kg}$ Ca diet. Hens can benefit from limestone grit supply when being fed a $40 \mathrm{~g} / \mathrm{kg}$ Ca diet which will help them to maintain their laying performance, egg quality, and production.

Author Contributions: Conceptualization, A.J.C. and C.J.O.; methodology, Y.A., S.B.; investigation, Y.A.; data curation, Y.A., D.C., S.M, P.H., and T.Z.S.; writing-original draft preparation, Y.A., S.M., I.R., and C.J.O.; writing-review and editing, I.R., Y.A., A.J.C., S.W., T.Z.S., M.S., and C.J.O.; supervision, C.J.O. and M.S.; project administration, Y.A.; funding acquisition, A.J.C. and S.W.; All authors have read and agreed to the published version of the manuscript.

Funding: This research was funded by the Australian Egg Corporation Limited Research Project 1 US112.

Institutional Review Board Statement: The experimental procedures that were conducted in this study were approved by the University of Sydney Animal Ethics Committee (Project Number 2016/945) and were conducted in accordance with the Australian code for the care and use of animals for scientific purposes.

Informed Consent Statement: Not applicable.

Data Availability Statement: Data is available upon request from the corresponding authors.

Acknowledgments: The authors would like to acknowledge the technical assistance of Joy Gill and her team at the Poultry Research Foundation, Camden, University of Sydney.

Conflicts of Interest: The authors declare no conflict of interests. The funders had no role in the design of the study; in the collection, analyses, or interpretation of data; in the writing of the manuscript, or in the decision to publish the results.

\section{References}

1. Shafey, T.M.; McDonald, M.W.; Dingle, J.G. Effects of dietary calcium and available phosphorus concentration on digesta pH and on the availability of calcium, iron, magnesium and zinc from the intestinal contents of meat chickens. Brit. Poult. Sci. 1991, 32, 185-194. [CrossRef] [PubMed]

2. Morgan, N.K.; Walk, C.L.; Bedford, M.R.; Burton, E.J. The effect of dietary calcium inclusion on broiler gastrointestinal pH: Quantification and method optimization. Poult. Sci. 2014, 93, 354-363. [CrossRef] [PubMed]

3. Taylor, T.C. The availability of the calcium and phosphorus of plant materials for animals. Proc. Nutr. Soc. 1965, $24,105-112$. [CrossRef] [PubMed]

4. Selle, P.H.; Cowieson, A.J.; Ravindran, V. Consequences of calcium interactions with phytate and phytase for poultry and pigs. Livest. Sci. 2009, 124, 126-141. [CrossRef] 
5. Jiang, S.; Cui, L.; Shi, C.; Ke, X.; Luo, J.; Hou, J. Effects of dietary energy and calcium levels on performance, egg shell quality and bone metabolism in hens. Vet. J. 2013, 198, 252-258. [CrossRef] [PubMed]

6. Cufadar, Y.; Olgun, O.; Yildiz, A.Ö. The effect of dietary calcium concentration and particle size on performance, eggshell quality, bone mechanical properties and tibia mineral contents in moulted laying hens. Brit. Poult. Sci. 2011, 52, 761-768. [CrossRef]

7. Holcombe, D.J.; Roland, D.A.; Harms, R.H. The ability of hens to adjust calcium intake when given a choice of diets containing two levels of calcium. Poult. Sci. 1975, 54, 552-561. [CrossRef] [PubMed]

8. Rose, S.P.; Kyriazakis, I. Diet selection of pigs and poultry. Proc. Nutr. Soc. 1991, 50, 87-98. [CrossRef] [PubMed]

9. Wilkinson, S.J.; Selle, P.H.; Bedford, M.R.; Cowieson, A.J. Exploiting calcium-specific appetite in poultry nutrition. World Poult. Sci. J. 2011, 67, 587-598. [CrossRef]

10. Joshua, I.G.; Mueller, W.J. The development of a specific appetite for calcium in growing broiler chicks. Brit. Poult. Sci. 1979, 20, 481-490. [CrossRef]

11. Kyriazakis, I.; Tolkamp, B.J.; Emmans, G. Diet selection and animal state: An integrative framework. Proc. Nutr. Soc. 1999, 58, 765-772. [CrossRef] [PubMed]

12. Wilkinson, S.J.; Selle, P.H.; Bedford, M.R.; Cowieson, A.J. Separate feeding of calcium improves performance and ileal nutrient digestibility in broiler chicks. Anim. Prod. Sci. 2014, 54, 172-178. [CrossRef]

13. Snow, J.L.; Douglas, M.W.; Parsons, C.M. Phytase effects on amino acid digestibility in molted laying hens. Poult. Sci. 2003, 82, 474-477. [CrossRef] [PubMed]

14. Lim, H.S.; Namkung, H.; Paik, I.K. Effects of phytase supplementation on performance, egg quality and phosphorus excretion of laying hens fed different levels of dietary calcium and nonphytate phosphorus. Poult. Sci. 2003, 82, 92-99. [CrossRef] [PubMed]

15. Brennan, S.C.; Davies, T.S.; Schepelmann, M.; Riccardi, D. Emerging roles of the extracellular calcium-sensing receptor in nutrient sensing: Control of taste modulation and intestinal hormone secretion. Brit. J. Nutr. 2014, 111, S16-S22. [CrossRef]

16. National Health and Medical Research Council (Australia); Australian Research Council. Australian Code for the Care and Use of Animals for Scientific Purposes; National Health and Medical Research Council: Australia, 2013.

17. ISA Brown. Nutrition Management Guide; Institut de Selection Animale, BV: Boxmeer, The Netherlands, 2011.

18. Şekeroğlu, A.; Altuntaş, E. Effects of egg weight on egg quality characteristics. J. Sci. Food Agr. 2009, 89, 379-383. [CrossRef]

19. Hill, F.W.; Anderson, D.L. Comparison of metabolizable energy and productive energy determinations with growing chicks. $J$. Nutr. 1958, 64, 587-603. [CrossRef]

20. SAS University Edition; SAS Institute Inc.: Cary, NC, USA.

21. Kassambara, A. Rstatix: Pipe-Friendly Framework for Basic Statistical Tests; R Package Version 0.7.0. 2020; Available online: https: / /CRAN.R-project.org/package=rstatix (accessed on 9 July 2021).

22. Meunier-Salaün, M.C.; Faure, J.M. On the feeding and social behaviour of the laying hen. Appl. Anim. Behav. Sci. 1984, 13, 129-141. [CrossRef]

23. Cransberg, P.H.; Parkinson, G.B.; Wilson, S.; Thorp, B.H. Sequential studies of skeletal calcium reserves and structural bone volume in a commercial layer flock. Brit. Poult. Sci. 2001, 42, 260-265. [CrossRef]

24. Ziaei, N.; Shivazad, M.; Mirhadi, S.A.; Gerami, A. Effects of reduced calcium and phosphorous diets supplemented with phytase on laying performance of hens. Pak. J. Biol. Sci. 2009, 12, 792-797. [CrossRef]

25. Leeson, S.; Summers, J.D. Influence of nutritional modification on skeletal size of leghorn and broiler breeder pullets. Poult. Sci. 1984, 63, 1222-1228. [CrossRef] [PubMed]

26. Röhe, I.; Ruhnke, I.; Knorr, F.; Mader, A.; Boroojeni, F.G.; Löwe, R.; Zentek, J. Effects of grinding method, particle size, and physical form of the diet on gastrointestinal morphology and jejunal glucose transport in laying hens. Poult. Sci. 2014, 93, 2060-2068. [CrossRef] [PubMed]

27. Ruhnke, I.; Röhe, I.; Krämer, C.; Boroojeni, F.G.; Knorr, F.; Mader, A.; Schulze, E.; Hafeez, A.; Neumann, K.; Löwe, R.; et al. The effects of particle size, milling method, and thermal treatment of feed on performance, apparent ileal digestibility, and $\mathrm{pH}$ of the digesta in laying hens. Poult. Sci. 2015, 94, 692-699. [CrossRef] [PubMed]

28. Kim, J.H.; Pitargue, F.M.; Jung, H.; Han, G.P.; Choi, H.S.; Kil, D.Y. Effect of superdosing phytase on productive performance and egg quality in laying hens. Asian Austral. J. Anim. 2017, 30, 994-998. [CrossRef]

29. Fernández, S.R.; Chárraga, S.; Ávila-Gonzalez, E. Evaluation of a new generation phytase on phytate phosphorus release for egg production and tibia strength in hens fed a corn-soybean meal diet. Poult. Sci. 2019, 98, 2087-2093. [CrossRef]

30. Driver, J.P.; Pesti, G.M.; Bakalli, R.I.; Edwards, J.H.M. Effects of calcium and nonphytate phosphorus concentrations on phytase efficacy in broiler chicks. Poult. Sci. 2005, 84, 1406-1417. [CrossRef] 